\title{
Two new species of Novantinoe (Disteniini, Disteniidae), two new species of Eurysthea (Elaphidiini, Cerambycinae, Cerambycidae), and new geographical records
}

\author{
Juan Pablo Botero ${ }^{1,3}$; Daniel Heffern ${ }^{2}$ \& Antonio Santos-Silva ${ }^{1,4}$ \\ 1 Universidade de São Paulo (USP), Museu de Zoologia (MZUSP). São Paulo, SP, Brasil. \\ 2 Houston, Texas, USA. E-mail: titanusgiganteus@hotmail.com \\ 3 ORCID: 0000-0002-5547-7987. E-mail:jp_bot@yahoo.com \\ 4 ORCID:0000-0001-7128-1418. E-mail: toncriss@uol.com.br
}

\begin{abstract}
Two new species of Novantinoe from Mexico, N. oaxaquena and N. fabiolae; and two new species of Eurysthea, E. nogueirai, from Mexico, and E. nakagomei from Colombia are described. Furthermore, geographical distributions of three species are expanded.
\end{abstract}

Key-Words. Cerambycoidea; Colombia; Mexico; Taxonomy.

\section{INTRODUCTION}

The families Cerambycidae and Disteniidae, together with Oxypeltidae and Vesperidae comprise the informal clade called Cerambycoidea, which with Megalopodidae, Orsodacnidae and Chrysomelidae represent the Chrysomeloidea superfamily (Švácha \& Lawrence, 2014). Currently, the family Cerambycidae comprises eight subfamilies and about 38,000 species and the family Disteniidae four tribes and about 400 species (Švácha \& Lawrence, 2014; Tavakilian \& Chevillotte, 2018).

The genus Novantinoe, allocated in the family Disteniidae, was proposed by Thomson (1864) under the name Antinoe, and subsequently synonymized by Lacordaire (1869) with Distenia Lepeletier \& Audinet-Serville, 1828. Santos-Silva \& Hovore (2007a) revalidated the genus to accommodate species previously assigned in Distenia and because the name Antinoe Thomson, 1864 was preoccupied by Antinoe Kinberg, 1856 (Annelidae, Polychaeta, Polynoidae, Harmothoinae) the authors proposed the nomen novum Novantinoe. Santos-Silva \& Hovore (2007b) revised the entire genus, and Santos-Silva \& Martins (2010) revised the South American species. Currently, the genus encompasses 37 described species, distributed from southern Mexico to southern South America, of which there are five with geographical distribution recorded from Mexico (Monné, 2018; Tavakilian \& Chevillotte, 2018).
Into the family Cerambycidae, Eurysthea was described by Thomson (1860) and, recently, it was revised by Botero \& Santos-Silva (2017). Currently, this genus is composed of 23 species distributed mainly in South America, with only one of them occurring also in Central America, E. cribripennis Bates, 1885. From Mexico there is not any species of Eurysthea reported; in Colombia there are currently six reported species (Monné, 2018; Tavakilian \& Chevillotte, 2018).

\section{MATERIAL AND METHODS}

Photographs were taken with a Canon EOS Rebel T3i DSLR camera, Canon MP-E $65 \mathrm{~mm}$ f/2.8 1-5X macro lens, controlled by Zerene Stacker AutoMontage software. Measurements were taken in "mm" using measuring ocular Hensoldt/ Wetzlar - Mess 10 in the Leica MZ6 stereomicroscope, also used in the study of the specimens. The references and geographical distribution were consulted at Monné (2018), and Tavakilian \& Chevillotte (2018) catalogs. The acronyms used in the text are as follows:

CNIN: Colección Nacional de Insectos, Instituto de Biología (UNAM), Mexico City, Mexico;

DHCO: Daniel Heffern Collection, Houston, Texas, USA;

MZSP: Museu de Zoologia, Universidade de São Paulo, São Paulo, Brazil. 


\section{RESULTS}

\section{Disteniidae}

\section{Disteniini}

\section{Novantinoe oaxaquena Botero, Heffern \& Santos-Silva, new species} (Figs. 1-4)

Description: Male: Integument mostly brownish, slightly darker on some areas; mouthparts, apex of antennal tubercles, yellowish-brown; scape dark reddish-brown; pedicel yellowish-brown basally; antennomeres III-X reddish-brown on basal 3/4 (more yellowish-brown depending on intensity of light), gradually darkened on distal quarter, especially on III-VII; prosternal process gradually reddish-brown toward apex; elytra reddish-brown on anterior third, gradually yellowish-brown toward apex, except dark brown triangular area on anterior sixth around scutellum, oblique dark brown band dorsally, from about apex of anterior quarter to before middle (together V-shaped), slightly distinct, irregular brown macula dorsally after middle, and dark brown punctures on anterior $3 / 4$; femora reddish-brown, slightly darkened toward apex; tibiae with basal dark reddish-brown ring, reddish-brown (more yellowish-brown depending on intensity of light) on wide central area, and slightly, gradually darkened toward apex; tarsi reddish-brown except blackish apex of claws. Pubescence somewhat golden; erect setae pale yellow.

Head: Frons narrow, vertical; pubescence not obscuring integument. Antennal tubercles elevated, close to each other, separated by deep sulcus, with apex rounded, more distinctly elevated; pubescence not obscuring integument, distinctly sparser along dorsal surface. Vertex minutely, sparsely punctate, gradually coarser, denser toward prothoracic margin (partially confluent close to prothorax); pubescence not obscuring integument, denser close to antennal tubercles and sides after middle of upper eye lobes, nearly glabrous close to prothorax (slightly bristly on some areas). Area behind upper eye lobes minutely, sparsely punctate toward inner margin, coarser, abundant on its central area, especially toward prothorax, finer, sparser toward lower eye lobe; pubescence abundant, not obscuring integument, except glabrous area close to prothorax, gradually sparser, present only close to eyes toward lower eye lobe; with a few long, erect setae close to eye. Area behind lower eye lobes finely, sparsely punctate, slightly transversely striate centrally; pubescent close to eye, gradually glabrous toward prothorax. Genae very finely, transversely striate on basal $3 / 4$ close to eye, smooth on distal quarter; with moderately sparse pubescence on basal 3/4, glabrous on distal quarter. Gulamentum smooth except slightly rugose anterior area; with sparse pubescence laterally at about anterior half, more abundant close to eyes, and on slightly rugose area; rugose area with sparse, elongated erect setae. Postclypeus large, sub-horizontal, slightly convex and longitudinally sulcate close to frons, slightly inclined toward labrum; finely, moderately abundantly punctate on sub-horizontal area, except smooth central area, nearly smooth on remaining surface; with moderately long (especially toward anterior margin), nearly decumbent, abundant setae laterally, smooth centrally (this latter area gradually widened toward anterior margin). Labrum coplanar with anteclypeus at posterior third, gradually inclined toward anterior margin at distal $2 / 3$; finely, moderately abundantly punctate, especially on posterior third; with long, erect, moderately abundant setae, absent close to anteclypeus, and fringe of short setae at anterior margin. Maxillary palpomere IV widened toward apex, but not distinctly securiform, with distal margin oblique. Inner margin of upper eye lobes large, rounded. Distance between upper eye lobes 0.27 times length of scape; distance between lower eye lobes ventrally, 0.61 times length of scape. Antennae 2.0 times elytral length, reaching elytral apex at about distal quarter of antennomere VII. Scape moderately coarsely, densely punctate (slightly rugose); pubescence not obscuring integument, nearly glabrous ventrally, interspersed with a few elongated, erect setae. Antennomeres with pubescence distinctly exposing integument; with a few elongated, erect setae at apex of III-X. Antennal formula based on antennomere III: scape $=0.87$; pedicel $=0.14$; $\mathrm{IV}=0.98 ; \mathrm{V}=0.96 ; \mathrm{VI}=0.96 ; \mathrm{VII}=0.93 ; \mathrm{VIII}=0.86 ; \mathrm{IX}=0.77$; $\mathrm{X}=0.67 ; \mathrm{XI}=0.72$.

Thorax: Prothorax 1.45 times wider than long (including lateral tubercles); lateral tubercles large, conical, placed at middle; anterior margin slightly narrower than posterior one. Pronotum with five distinct tubercles: one on each side of anterior half, nearly conical, higher than the others; one on each side of posterior half; another centrally, subelliptical, slightly sulcate longitudinally. Pronotal pubescence abundant, not obscuring integument, except on glabrous central tubercle and top of lateral tubercles of disc; anterior and posterior constrictions well-marked; central area, among tubercles, minutely, abundantly punctate (sparsely on central gibbosity); remaining surface nearly smooth. Sides of prothorax with abundant pubescence, partially obscuring integument, between anterior and posterior constrictions, sparsely pubescent on remaining surface. Prosternum sparsely pubescent close to procoxal cavities and laterally, with very sparse setae on remaining surface. Mesoventrite with pubescence distinctly exposing integument, glabrous laterally. Mesanepisternum and mesepimeron with pubescence denser than on mesoventrite. Metanepisternum and metaventrite with abundant pubescence not obscuring integument, except central, triangular area of metaventrite with pubescence distinctly sparser. Scutellum with pubescence obscuring integument.

Elytra: Coarsely, abundantly punctate on anterior third, gradually finer, sparser toward apex (lateral punctures aligned); pubescence abundant, partially obscuring integument; posterior third with elongated setae on margins; apex narrowly rounded (nearly triangular). 

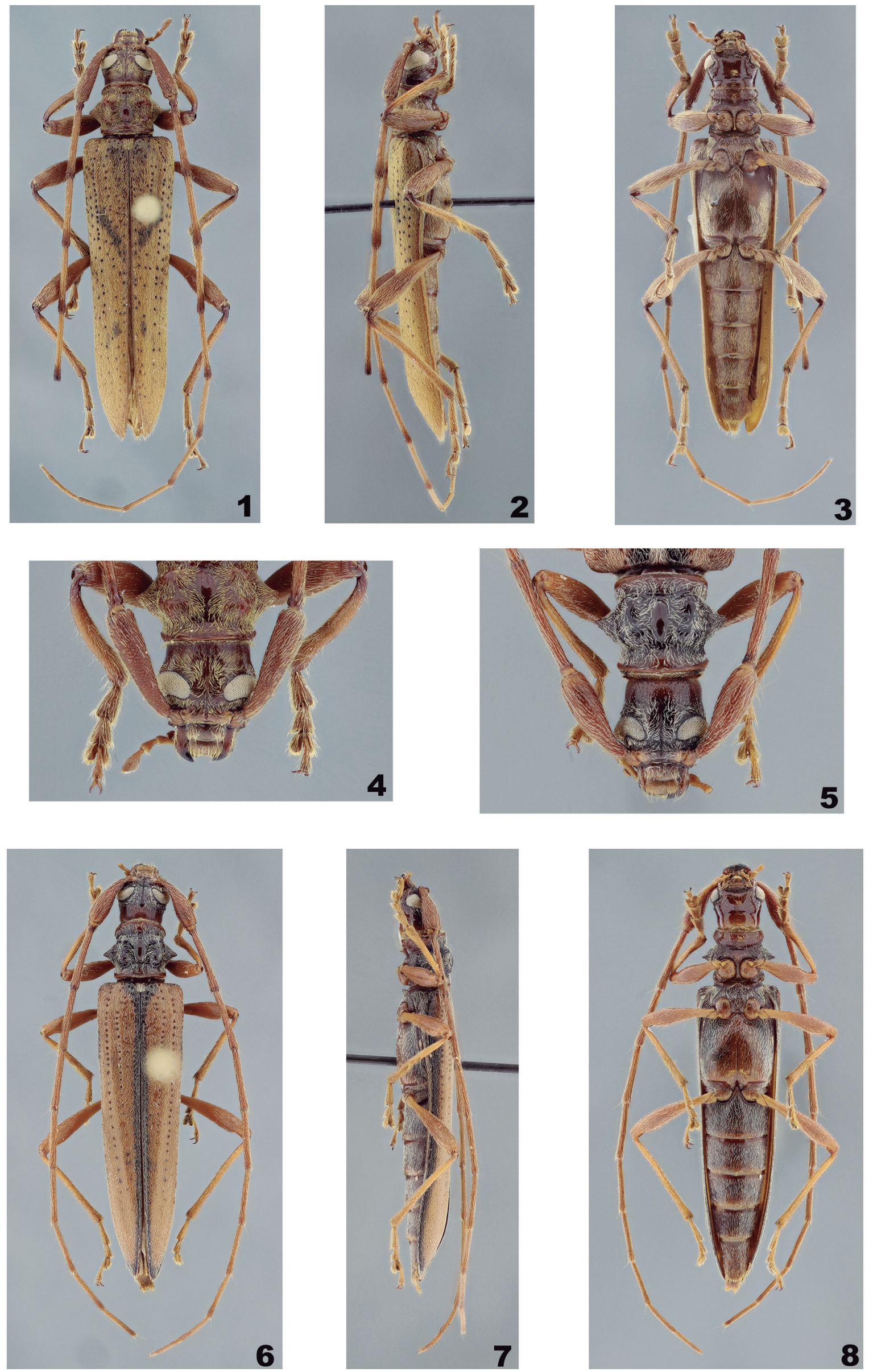

Figures 1-8: (1-4) Novantinoe oaxaquena sp. nov., holotype, male: (1) dorsal view; (2) lateral view; (3) ventral view; (4) detail of head, dorsal view. (5-8) Novantinoe fabiolae sp. nov., holotype, female: (5) detail of head, dorsal view; (6) dorsal view; (7) lateral view; (8) ventral view. 
Legs: Profemora fusiform; meso- and metafemora clavate; pubescence not obscuring integument. Protibiae wider than meso- and metatibiae, somewhat curved from base to near apex, which is slightly wider; ventral side with pubescence not obscuring integument, interspersed with elongated erect setae; dorsal side with suberect setae, sparser on protibiae. Metatarsomere I longer than II-III together.

Abdomen: Ventrites with abundant pubescence, not obscuring integument, except on glabrous posterior area of I-IV, and nearly glabrous basal area of V; ventrite I slightly shorter than ventrite II; apex of ventrite $\mathrm{V}$ truncate.

Dimensions (mm): Total length, 19.30; prothoracic length, 2.40; posterior prothoracic width, 2.45; anterior prothoracic width, 2.30; maximum prothoracic width (between apices of lateral tubercles), 3.45; humeral width, 4.15; elytral length, 14.00.

Type Material: Holotype male from MEXICO, Oaxaca: Concepción Pápalo (2,275 m), 10.VII.1997, G. Nogueira col. (CNIN).

Remarks: Novantinoe oaxaquena sp. nov. is similar to N. cristinae Santos-Silva \& Hovore, 2007; N. hefferni Santos-Silva \& Hovore, 2007; and N. payettei Santos-Silva \& Le Tirant, 2016 by its general appearance, the elytra bicolourus, and the inner and outer apical projections of metafemora subequal in length and with the same shape. It differs from $N$. cristinae by the body slender (wider in males of N. cristinae), head + prothorax slightly shorter than three times elytral length (slightly longer than twice elytral length in males of $N$. cristinae), pronotal and elytral pubescence more abundant (sparser in N. cristinae), elytral apex narrowly rounded (obliquely truncate in males of $N$. cristinae), and profemora without short spines ventrally (present in males of $N$. cristinae). The new species differs from $N$. hefferni by the head + prothorax slightly shorter than three times elytral length (2.5 times in N. hefferni), elytra slightly narrowed toward apex (distinctly narrowed toward apex in N. hefferni), elytral apex narrowly rounded (nearly acute in males of $N$. hefferni). Novantinoe oaxaquena sp. nov. differs from males of $N$. payettei by the slender body (wider in N. payettei), scape slender (distinctly widened in N. payettei), and elytral apex narrowly rounded (with distinct spine at outer angle in N. payettei). The general appearance of the new species also resembles $N$. noguerai Santos-Silva \& Le Tirant, 2016, but differs from it by the maxillary palpomere IV not distinct securiform (securiform in males of $N$. noguerai), scape slender (wider in N. noguerai), and elytral apex narrowly rounded (spiniform in N. noguerai). For comparisons, photographs of the holotypes of N. cristinae, N. payettei, N. noguerai, and N. hefferni are available in Bezark (2018).

Etymology: The epithet, oaxaquena, is a demonym alluding to the inhabitants of Oaxaca state, in Mexico, the locality where the specimen was collected.

\section{Novantinoe fabiolae \\ Botero, Heffern \& Santos-Silva, new species}

(Figs. 5-8)

Description: Female: Head dark brown dorsally, gradually brown toward prothorax; apex of antennal tubercles light reddish-brown; ventral side brown (slightly reddish depending on angle of light), gradually light reddish-brown toward prothorax; postclypeus reddish-brown except dark brown area close to frons; labrum reddish-brown (yellowish-brown depending on intensity of light); palpi reddish-brown; antennae reddish-brown, with dark brown ring on apex of some antennomeres; pronotum dark brown on wide central area, gradually reddish-brown toward anterior and posterior margins; prosternum reddish-brown anteriorly, gradually brown toward prosternal process and dark brown toward sides of posterior half; ventral surface of mesothorax brown centrally (more dark reddish-brown depending on intensity of light), dark brown laterally; metanepisternum and sides of metaventrite dark brown, and remaining surface of metaventrite reddish-brown; elytra reddish-brown except dark brown band along suture (anteriorly involving scutellum), and dark brown band along epipleura (both bands fused at apex); femora reddish-brown; tibiae yellowish-brown, gradually light reddish-brown toward apex; tarsi light reddish-brown; abdominal ventrites I-IV dark brown except slightly reddish central posterior half, and transverse yellowish-brown distal area; abdominal ventrite $\mathrm{V}$ dark brown on basal half, gradually dark reddish-brown toward apex. Pubescence yellowish-white, more golden on antennae, tibiae and tarsi.

Head: Frons narrow vertical; pubescence forming narrow transverse band on each side of center close to postclypeus, nearly absent on remaining surface. Antennal tubercles elevated, close each other, separated by shallow sulcus, with apex rounded, more distinctly elevated; with moderately sparse pubescence except glabrous apex. Vertex finely, moderately sparsely punctate between antennal tubercles and posterior margin of upper eye lobes, slightly coarser, denser toward prothorax; pubescence moderately sparse between antennal tubercles and middle of area between upper eye lobes and prothorax, then gradually shorter and sparser, absent close to prothoracic margin. Area behind upper eye lobes finely, moderately abundant punctate (punctures denser close to eye); with pubescence not obscuring integument close to eye, glabrous on remaining surface; with a few long, erect pale yellow setae. Area behind lower eye lobes nearly smooth on tumid area close to eye, finely, sparsely punctate toward prothorax; with sparse pubescence close to eye, glabrous on remaining surface. Genae with sparse pubescence along central area, glabrous close to lower eye lobe and apex. Gulamentum smooth except rugose-punctate anterior area; tumid between lower eye lobes, transversely sulcate close to rugose-punctate area; with sparse pubescence laterally at about anterior third and on rugose-punctate area, more abundant close to eyes, with a few elongated erect setae 
interspersed. Postclypeus large, sub-horizontal, slightly convex, finely, moderately sparsely punctate close to frons, inclined, smooth toward labrum; pubescent on punctate area (laterally with longer setae interspersed), glabrous anteriorly. Labrum coplanar with anteclypeus at posterior half, gradually inclined toward anterior margin (depressed on center of anterior half); with both short and elongated setae along transverse central area. Maxillary palpomere IV slightly, gradually widened toward oblique apex. Upper eye lobes moderately narrow. Distance between upper eye lobes 0.32 times length of scape; distance between lower eye lobes ventrally 0.64 times length of scape. Antennae 1.8 times elytral length, reaching elytral apex at distal third of antennomere VIII. Scape distinctly widened toward apex; moderately finely, abundant punctate on basal third, gradually finer, sparser toward apex; pubescence not obscuring integument; with a few long, erect setae dorsally on distal area. Antennomeres with pubescence distinctly exposing integument; with a few elongated, erect setae at apex of III-X; with very long, moderately abundant setae ventrally on III-XI. Antennal formula based on antennomere III: scape $=0.88$; pedicel $=0.14 ; \mathrm{IV}=0.98 ; \mathrm{V}=0.96 ; \mathrm{VI}=0.93$; $\mathrm{VII}=0.88 ; \mathrm{VIII}=0.82 ; \mathrm{IX}=0.75 ; \mathrm{X}=0.65 ; \mathrm{XI}=0.65$.

Thorax: Prothorax 1.28 times wider than long (including lateral tubercles); lateral tubercles large, conical, placed at middle; anterior margin as wide as posterior margin. Pronotum with five distinct tubercles, lateral ones together forming large gibbosity: one on each side of anterior half, nearly conical, higher than the others, with apex slightly directed sideward; one on each side of posterior half, with rounded apex; another centrally, elongated. Pronotal pubescence abundant, not obscuring integument, except on glabrous central tubercle; anterior and posterior constrictions well-marked; central area, among tubercles, finely, moderately sparsely punctate; remaining surface nearly smooth. Sides of prothorax with moderately abundant pubescence between anterior and posterior constrictions, not obscuring integument, sparsely pubescent on remaining surface. Prosternum sparsely pubescent close to procoxal cavities and laterally (especially on posterior half), with very sparse setae on remaining surface. Mesoventrite with pubescence not obscuring integument. Mesanepisternum with pubescence slightly denser than on mesoventrite and mesepimeron. Metanepisternum and metaventrite with abundant pubescence not obscuring integument, except central area of metaventrite with sparse pubescence (glabrous along central discrimen). Scutellum with pubescence obscuring integument.

Elytra: With five rows of coarse punctures (punctures absent on posterior third): one close to suture, reaching about posterior third; three more dorsally (innermost reaching only apex of anterior third; outermost reaching posterior third; central one slightly distinct after middle); one laterally, reaching about middle; pubescence abundant, not obscuring integument; with elongated setae laterally on posterior quarter; apex very narrowly rounded.
Legs: Profemora fusiform; meso- and metafemora clavate; pubescence not obscuring integument, with a few long, erect setae interspersed. Protibiae widened at posterior quarter; with sparse pubescence, denser ventrally on distal half. Metatarsomere I about as long as II-III together.

Abdomen: Ventrites with abundant pubescence, not obscuring integument (sparser centrally on posterior half of I-IV), except on glabrous posterior area of I-IV; ventrite I subequal in length to ventrite II; apex of ventrite $V$ rounded.

Dimensions (mm): Total length, 17.40; prothoracic length, 2.35; posterior prothoracic width, 2.10; anterior prothoracic width, 2.10; maximum prothoracic width (between apices of lateral tubercles), 3.00; humeral width, 3.45; elytral length, 12.20 .

Type Material: Holotype male from MEXICO, Oaxaca: Sierra de Juarez (850 m), 15.V.1998, G. Nogueira col. (CNIN).

Remarks: The general appearance of Novantinoe fabiolae sp. nov. (female) is as that of $N$. hefferni (male). However, the scape (Fig. 5) is abruptly widened toward apex and is not rugose. In N. hefferni, the scape (see in Bezark, 2018) is more gradually widened toward apex and is distinctly rugose. As we never saw this kind of sexual dimorphism in the other species of Neotropical Disteniinae, we believe that they belong to different species. Novantinoe fabiolae differs from $N$. cristinae by the denser pubescence on pronotum and elytra (sparse in both sexes of N. cristinae); from N. payettei by the pronotal and elytral pubescence denser, and upper eye lobes narrower (pubescence sparse and upper eye lobes wider in N. payettei); from $N$. noguerai by the elytral punctures sparser and upper eye lobes narrower (punctures more abundant and upper eye lobes wider in N. noguerai); and from $N$. oaxaquena sp. nov. by the scape wider and not rugose (slender and rugose in N. oaxaquena), and by the posterior third of the elytra more uniformly narrowed toward apex (somewhat rounded narrowed in N. oaxaquena).

Etymology: This species is named after Fabiola Lopez C., the wife of Guillermo Nogueira collector of the holotype. This is in deep appreciation for her years of support of his work in entomology.

\section{Cerambycidae}

Cerambycinae

Elaphidiini

Eurysthea nogueirai

Botero, Heffern \& Santos-Silva, new species

(Figs. 9-12)

Description: Female: Integument dark brown; scape dark reddish-brown, pedicel and flagellomere reddish. 
Head: Frons short, smooth medially, with a deep transverse sulcus; opaque, minutely, densely punctate between plate and clypeus, interspersed with some fine punctures; with decumbent, moderately abundant, golden setae. Area between antennal tubercles with coarse sparse punctures, slightly carinate; with long, decumbent, abundant golden setae, interspersed with elongated erect setae. Area between upper eye lobes coarsely punctate, smooth centrally; with decumbent, abundant, golden setae, interspersed with some long, erect setae, glabrous centrally. Median groove distinct from fronto-clipeal suture to middle of area between antennal tubercles. Antennal tubercles slightly elevated, rounded at apex, finely sparsely punctate. Genae coarsely, sparsely punctate; with decumbent, long, sparse golden setae. Gula smooth, glabrous. Submentum slightly striate-punctate; with long, erect, moderately abundantly yellowish-white setae. Mandibles coarsely, confluently punctate, smooth distally and toward inner side; with some short and long, moderately sparse, sub-erect yellowish-white setae (long setae more erect). Distance between upper eye lobes about $2 / 3$ length of scape; distance between lower eye lobes in frontal view equal to length of scape. Antennae 1.16 times elytral length, reaching elytral apex at apex of antennomere IX. Scape slightly, gradually enlarged toward apex; coarsely and densely punctuate, slightly finer and sparser at apex; with decumbent, moderately abundant, short, yellowish-white setae interspersed with long, yellowish-white setae. Antennomeres III-XI with short, decumbent, abundantly yellowish-white pubescence; with elongated, erect, yellowish-white setae on inner side and at apex of each antennomere (gradually shorter, sparser toward distal segments). Antennomere III carinate at apex, with long spine at inner apex (as long as 0.17 times length of antennomere; 0.21 times length of antennomere IV). Antennomere IV carinate, with elongated spine at inner apex (as long as 0.22 times length of antennomere). Antennomere V-VII with spine at inner apex, antennomere VIII with short spiniform projection at inner apex. Antennomeres IX-XI unarmed at apex. Antennal formula (ratio) based on antennomere III (without spine): scape $=0.66$; pedicel $=0.18 ; \mathrm{IV}=0.78 ; \mathrm{V}=0.76 ; \mathrm{VI}=0.80$; $\mathrm{VII}=0.78 ; \mathrm{VIII}=0.66 ; \mathrm{IX}=0.64 ; \mathrm{X}=0.51 ; \mathrm{XI}=0.54$.

Thorax: Prothorax slightly wider than long, sides with small, spiniform tubercle before middle (apex truncated); coarsely, densely punctate except subsmooth, transverse band at anterior and posterior margin and on gibbosities; with short, abundant, golden setae (not obscuring integument), interspersed with elongated erect setae. Pronotum with five gibbosities, slightly elevated: two sub-circular, placed at each side just after middle; two sub-circular, placed on each side of posterior quarter; and one elongated, from midlength to posterior quarter. Pronotal surface coarsely, moderately sparsely punctate between gibbosities; area outside of region delimited by gibbosities coarsely, densely punctate; with short, golden setae (not obscuring integument), slightly denser between gibbosities, with long, erect, sparse, yellow- ish-white setae, mainly between gibbosities. Prosternum, transversely striate (subsmooth on some areas) on anterior third; with some sparse elongated erect yellowish setae, mainly on anterior third. Prosternal process at narrowest point, equal to 0.4 times the procoxal cavity width. Mesoventrite, mesepimeron and mesanepisternum with short, decumbent, sparse golden setae (slightly distinct depending on angle of light) interspersed with moderately short, sub-erect yellowish-white setae. Mesoventral process emarginate at apex, equal to 0.7 times the mesocoxal cavity. Metanepisternum with short, decumbent, abundant golden setae (almost indistinct depending on angle of light) interspersed with long, sub-erect, yellowish-white setae (more erect basally). Metaventrite coarsely punctate, sparser and finer toward median region and posterior margin; with short, decumbent, sparser golden setae; with some long, sub-erect, yellowish-white setae throughout.

Elytra: Moderately coarsely, abundantly punctate; with short decumbent, thick, yellowish-white setae throughout, interspersed with elongated erect sparse setae; apex obliquely truncate, with elongated spine at outer angle, sutural angle unarmed.

Legs: Apices of meso- and metafemora rounded; femora and tibiae with moderately long, abundant yellowish-white setae (denser toward apex of tibiae).

Abdomen: Ventrites finely, moderately abundantly punctate; with moderately sparse, decumbent, yellowish-white setae, interspersed with elongated erected setae. Ventrite V 0.85 times as long as IV; apex truncate.

Dimensions in mm (female): Total length, 17.1; prothorax length, 3.0; anterior prothoracic width, 2.1; posterior prothoracic width, 2.4; largest prothoracic width, 3.1; humeral width, 3.9; elytral length, 12.1.

Type Material: Holotype female from MEXICO, Guanajuato: Sierra de Santa Rosa, 2,250 m, 13-14.VII.1999, G. Nogueira col. (CNIN).

Etymology: Named in honor of Guillermo Nogueira, collector of the holotype.

Remarks: Eurysthea nogueirai sp. nov. resembles some specimens from E. hirca (Berg) 1889 without yellowish maculae on elytra (variable characteristic in that species) but differs by the shape of pronotum; the anterior gibbosities slightly elevated (more elevated in E. hirca); the elytra with sparse and uniform setae throughout (denser and forming patches of pubescence in E. hirca); and the elytral apex with only external spine (bispinose in $E$. hirca). By the absence of yellowish maculae on elytra, the new species also resembles E. sordida (Erichson, 1847), but differs from it by the elytral pubescence sparser (notably denser in E. sordida); and the elytral apex with spine at outer angle (elytral apex unarmed in E. sordida). Eurysthea nogueirai sp. nov. also differs from E. cribripen- 

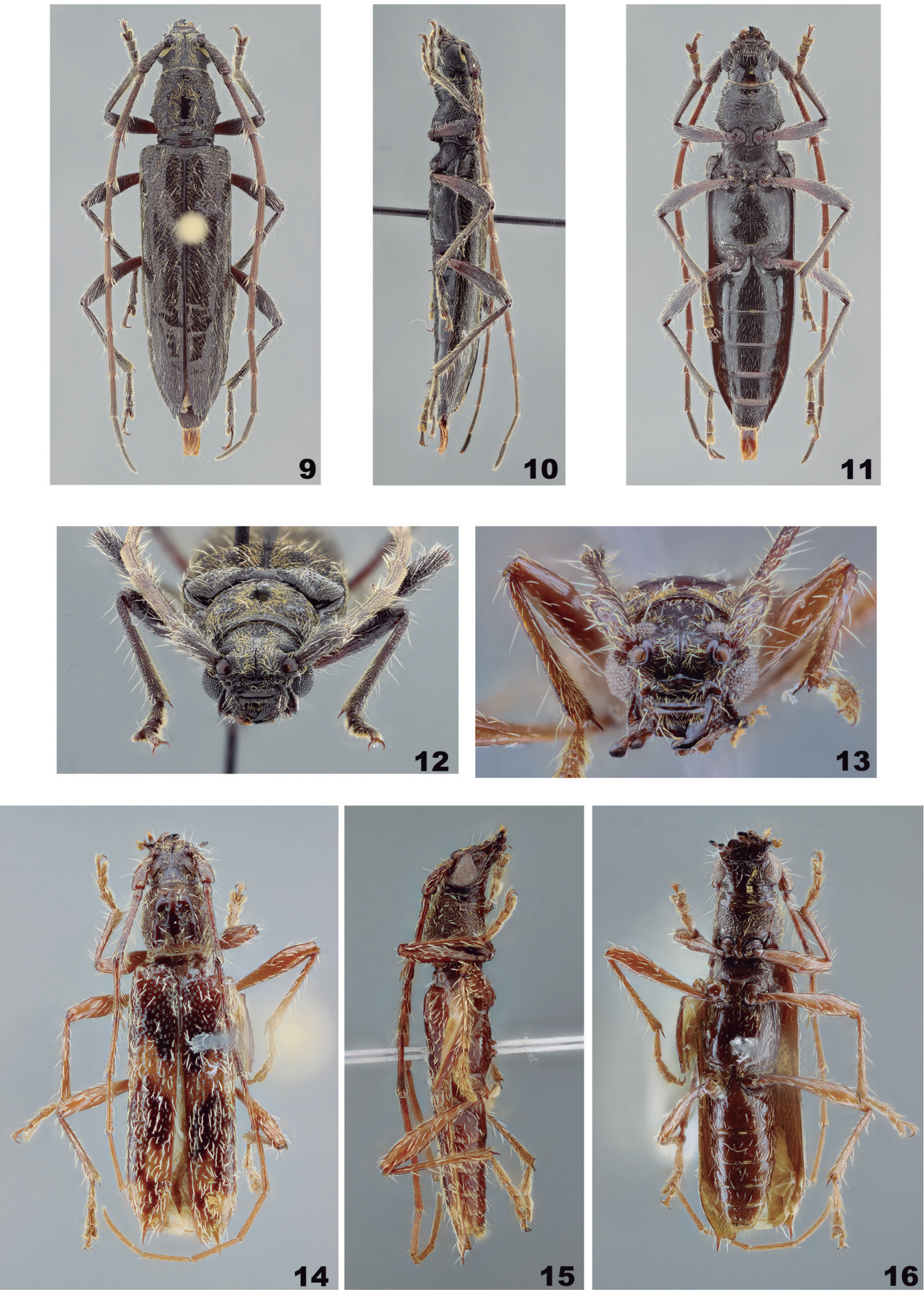

Figures 9-16: (9-12) Eurysthea nogueirai sp. nov., holotype, female: (9) dorsal view; (10) lateral view; (11) ventral view; (12) detail of head, dorsal view. (13-16) Eurysthea nakagomei sp. nov., holotype, male: (13) detail of head, dorsal view; (14) dorsal view; (15) lateral view; (16) ventral view. 
nis (Bates, 1885) by the antennomeres III-VII with distinct spine at inner apex (in E. cribripennis the spine is present just in antennomeres III-IV); by the elytra without yellowish maculae on elytra and with short decumbent setae interspersed with elongated erect sparse setae (with yellowish maculae and with decumbent setae in E. cribripennis); and by the elytral apex obliquely truncated (straightly truncated in E. cribripennis). Eurysthea nogueirai sp. nov. is the first species of the genus registered from Mexico.

\section{Eurysthea nakagomei \\ Botero, Heffern \& Santos-Silva, new species} (Figs. 13-16)

Description: Male: Integument reddish-brown; antennae lighter toward apex; each elytron with a yellow antemedian inverted macula "V" shaped and two yellow spots at apex; legs yellowish. Body with elongated sparse white erect setae.

Head: Frons short, with a transverse sulcus, minutely, densely punctate; with decumbent, abundant, golden setae and long white setae. Area between antennal tubercles with fine dense punctures, slightly carinate; with elongated, decumbent, abundant golden setae, interspersed with long sparse erect setae. Area between upper eye lobes finely sparsely punctate, smooth centrally; with some whitish elongated, erect setae, glabrous centrally. Antennal tubercles slightly elevated, rounded at apex, finely sparsely punctate. Genae finely, sparsely punctate; with decumbent, elongated, sparse golden setae at margin of ocular lobe. Gula finely punctuate, with long erect white setae. Mandibles coarsely, confluently punctate, smooth distally and toward inner side; with some short and long, moderately sparse, sub-erect yellowish-white setae (elongated setae more erect). Distance between upper eye lobes about $1 / 2$ length of scape; distance between lower eye lobes in frontal view equal to length of scape. Antennae reaching elytral apex at apex of antennomere VIII. Scape slightly, gradually enlarged toward apex; finely and sparsely punctuate, smooth at apex; with decumbent, sparse, long, whitish setae, interspersed with long, erect white setae. Antennomeres III-XI with moderately long, decumbent, sparse white setae, shorter and denser toward apical antennomeres; with long, erect, white setae on inner side and at apex of each antennomere (gradually shorter, sparser toward distal segments). Antennomere III not carinate, with elongated spine at inner apex (as long as 0.29 times length of antennomere). Antennomere IV not carinate, with elongated spine at inner apex (as long as 0.28 times length of antennomere). Antennomere V-XI unarmed at apex. Antennal formula (ratio) based on antennomere III (without spine): scape $=0.58 ;$ pedicel $=0.11 ; \mathrm{IV}=0.75 ; \mathrm{V}=0.79 ; \mathrm{VI}=0.75$; $\mathrm{VII}=0.78 ; \mathrm{VIII}=0.71 ; \mathrm{IX}=0.70 ; \mathrm{X}=0.64 ; \mathrm{XI}=0.79$.

Thorax: Prothorax longer than wide (1,17 times), sides curved, unarmed; finely sparsely punctate except smooth, transverse band at anterior margin and on gibbosities; with short, abundant, golden setae (not obscuring integument), except on transverse band at anterior margin and on gibbosities, interspersed with elongated erect setae. Pronotum with five gibbosities, slightly elevated: two sub-circular, placed at each side just after middle; two sub-circular, placed on each side of posterior quarter; and one longitudinal from midlength to posterior quarter. Prosternum coarsely densely punctuate; with some sparse moderately elongated white setae. Prosternal process subparallel, equal to 0.28 times the procoxal cavity width. Mesoventrite, mesepimeron and mesanepisternum with short, decumbent, dense golden setae (slightly distinct depending on angle of light) interspersed with moderately short, sub-erect yellowish-white setae. Mesoventral process emarginate at apex, equal to 0.6 times the mesocoxal cavity. Metanepisternum with short, decumbent, abundant golden setae (almost indistinct depending on angle of light) on anterior and lateral margins, glabrous on central region; interspersed with long, erect, white setae (more erect, abundant basally). Metaventrite finely punctate, sparser and finer toward median region and posterior margin; with short, decumbent, sparser golden setae; with some long, sub-erect, yellowish-white setae throughout.

Elytra: Moderately coarsely, abundantly punctate, sparser toward apex, on apex smooth; with short decumbent, thick, white setae throughout, interspersed with elongated erect sparse setae; apex obliquely truncate, with elongated spine at outer angle, sutural angle unarmed.

Legs: Apices of meso- and metafemora rounded.

Abdomen: Ventrites smooth; with short decumbent, thick, white setae laterally, central region glabrous, interspersed with some elongated erected setae. Apex of ventrite $\mathrm{V}$ curved.

Dimensions in $\mathbf{m m}$ (male): Total length, 10.3; prothorax length, 1.9; anterior width, 1.6; posterior width, 1.5; largest prothoracic width, 1.7; humeral width, 1.7; elytral length, 6.9.

Type Material: Holotype male from Colombia, Valle del Cauca: Municipio de la Cumbre (Vereda Chicoral, 033'ㄴㄷㄴ ${ }^{\prime \prime}$, 76³4'56"W), 22-26.III.2017, Sinyaev col. (MZSP).

Etymology: The new species is in honor of Nakagome Masaji (Japan), a renowned collector of insects. He is a personal friend of Anton Olegovich Kozlov (Russia), who sent and donated the holotype for MZSP collection, and requested the name as a special favor, to expresses his thankfulness and respect to him.

Remarks: By its general appearance, Eurysthea nakagomei is similar to E. cribripennis (Bates, 1885), but differs by the prothorax unarmed laterally (with antemedian tubercle and lateral spine in E. cribripennis), scutellum near- 
ly glabrous (covered with dense yellowish pubescence in E. cribripennis), and body with sparse moderately long white setae (in E. cribripennis the body is covered with denser and longer yellowish setae). Among the species of Eurysthea with the prothorax unarmed (E. barsevskisi Botero \& Santos-Silva, 2017; E. nearnsi Botero \& SantosSilva, 2017; E. parva Martins \& Galileo, 2013; E. rotundicollis (Martins, 1995)), the new species differs from all of them by the prothorax with sparse and fine pubescence (denser and obscuring the integument in these species), and the scutellum nearly glabrous (densely covered with yellowish pubescence in these species). The new species differs from E. barsevskisi Botero \& Santos-Silva, 2017; E. nearnsi Botero \& Santos-Silva, 2017; and E. rotundicollis (Martins, 1995) by the yellow anterior and posterior maculae being interrupted (continuous in those species).

\section{New Geographical Records}

\section{Cerambycidae}

Cerambycinae

Trachyderini

\section{Ancylocera bicolor (Olivier, 1795)}

Geographical distribution: United States, Guatemala (?). A new country record from Nicaragua (Matagalpa) is added.

Specimen examined: GUATEMALA, Matagalpa: Santa Maria de Ostuma, female, 09.V.1992, J.M. Maes col. (DHCO).

\section{Disteniidae}

\section{Disteniini}

\section{Elytrimitatrix (Grossifemora) irregularis (Linsley, 1935)}

Geographical distribution: Mexico (Mexico, Michoacán, Guerrero). A new state record from Jalisco (Mexico) is added.

Specimen examined: MEXICO, Jalisco: Sierra de Talpa $(1,720$ m), female, 08-09.VII.2009, G. Nogueira col. (DHCO).

\section{Novantinoe fulvopicta (Bates, 1885)}

Geographical distribution: Mexico (Veracruz), Guatemala. A new state record from Oaxaca (Mexico) is added.

Specimen examined: MEXICO, Oaxaca: Sierra de Juárez (1,700 m), female, 25.V.1996, G. Nogueira col. (DHCO).

\section{ACKNOWLEDGMENTS}

We express our sincere thanks to Anton Olegovich Kozlov (Russia), for the donation of the holotype of Eurysthea nakagomei. The first author thanks to "Fundação de Amparo à Pesquisa do Estado de São Paulo" (FAPESP) for a postdoctoral fellowship (process number 2017/17898-0). The second author expresses his appreciation to Guillermo Nogueira (Mexico) for the opportunity to examine Cerambycidae and Disteniidae which has collected.

\section{REFERENCES}

Bezark, L.G. 2018. A photographic Catalog of the Cerambycidae of the New World. Available at: https://apps2.cdfa.ca.gov/publicApps/plant/ bycidDB/wdefault.asp?w=n. Access in: 07/2018.

Botero, J.P. \& Santos-Silva, A. 2017. Review of the genus Eurysthea Thomson, 1861 (Coleoptera: Cerambycidae: Cerambycinae). Journal of Natural History, 51(45-46): 2721-2743.

Lacordaire, J.T. 1869. Histoire Naturelle des Insectes. Genera des Coléoptères, ou exposé méthodique et critique de tous les genres proposés jusqu'ici dans cet ordre d'insectes. Paris, Librairie Encyclopédique de Roret., v. 9, t. 1, 409p.

Monné, M.A. 2018. Catalogue of the Cerambycidae (Coleoptera) of the Neotropical region. Part I. Subfamily Cerambycinae. Available at: http:// cerambyxcat.com. Access in: 07/2018.

Santos-Silva, A. \& Hovore, F.T. 2007a. Divisão do gênero Distenia Lepeletier \& Audinet-Serville, notas sobre a venação alar em Disteniini, homonimías, sinonímia e redescrições (Coleoptera, Cerambycidae, Disteniinae). Papéis Avulsos de Zoologia, 46(1): 1-29.

Santos-Silva, A. \& Hovore, F.T. 2007b. Espécies de Novantinoe Santos-Silva \& Hovore (Coleoptera, Cerambycidae, Disteniinae). Lambilloinea, 107(4): 573-610.

Santos-Silva, A. \& Martins, U.R. 2010. Subfamília Parandrinae, In: Martins, U.R. (Org.). Cerambycidae Sul-americanos (Coleoptera) Taxonomia. São Paulo, Sociedade Brasileira de Entomologia. v. 11, p. 5-79.

Švácha, P. \& Lawrence, J.F. 2014. 2.4 Cerambycidae Latreille, 1802. In: Kristensen, N.P. \& Beutel, R.G. (Eds.). Handbook of zoology, Coleoptera, Beetles, Volume 3: Morphology and Systematics (Phytophaga). Berlim, Walter de Gruyter GmbH. p. 77-177.

Tavakilian, G. \& Chevillotte, H. 2018. Base de données Titan sur les Cerabycidés ou longicornes. internationales sur les Cerambycidae ou Longicornes. Available at: http://titan.gbif.fr/index.html. Access in: 07/2018.

Thomson, J. 1860. Essai d'une classification de la famille des cérambycides et matériaux pour servir a une monographie de cette famille. Paris, Bouchard-Huzard. xvi + 128p.

Thomson, J. 1864. Systema cerambycidarum ou exposé de tous les genres compris dans la famille des cérambycides et familles limitrophes. Liége, $\mathrm{H}$. Dessain. 352p. 